UDK: 070:004.738.5]

Izvorni znanstveni članak

Primljen 28. X. 2019.

Siniša Kovačić - Ilija Musa - Zoran Tomić

Hrvatska katolička mreža - Sveučilište u Mostaru

sinisa.kovacic77@gmail.com - ilija.musa@sum.ba - zoran.tomic@sum.ba

\title{
ONLINE MEDIJI I NOVINARSTVO NA DRUŠTVENIM MREŽAMA - ISTRAŽIVANJE NA PRIMJERU DRUŠTVENE MREŽE FACEBOOK
}

\section{Sažetak}

Razvojem interneta i informacijsko-komunikacijskih tehnologija mediji i novinarstvo doživjeli su revolucionarne promjene, a multimedijski karakter obrade vijesti promijenio je obrasce prikupljanja, produkcije, uređivanja i objavljivanja vijesti. Na primjeru uređivačkih politika na društvenoj mreži Facebook deset najčitanijih news portala u Hrvatskoj potvrđuje se da su tradicionalne novinarske vrijednosti, kvalitetno i objektivno novinarstvo pod snažnim pritiskom produktivnosti, učinkovitosti i profitabilnosti te da su online mediji sve ovisniji o društvenim mrežama. News portali obilno se koriste clickbaitingom i ostalim manipulativnim tehnikama kako bi povećali čitanost objava na društvenim mrežama, odnosno povećali viralnost nekih "mekih" vijesti. Svakodnevnim povećavanjem broja pratitelja preko društvenih mreža news portalima raste utjecaj, s time da je dominacija Facebooka bitno veća i trenutačno nije upitna.

Ključne riječi: online mediji; društvene mreže; lažne vijesti; medijske manipulacije; izvori informacija; digitalni marketing; javni interes 


\section{Uvod}

U Leksikonu mas-medija mediji masovnoga komuniciranja definirani su kao mediji „preko kojih se posreduju, u masovnim količinama, poruke i informacije, prema masovnoj publici ${ }^{{ }^{{ }_{1}}}$. Mediji više nisu samo posrednici u prenošenju informacija, već su kao glavni subjekti masovnoga komuniciranja kreatori društvene zbilje, poglavito svijeta politike. Određuju važnost društvenih i političkih fenomena određujući dnevni red (agenda setting), stvaraju društvene i političke događaje te tako bitno utječu na percepciju društva kroz (re)interpretaciju društvene zbilje i konstrukciju političkoga spektakla. Agenda je definirana kao pokušaj da se medijima odredi što je najvažnije pitanje dana i smatra se da je „često vođena političkim imperativom jer je kao takva dio vladine fleksibilne strategije za minimiziranje političkih problema. Nametanje političke agende izazov je s jedne strane, ali i rutinski posao s druge ${ }^{{ }}{ }_{2}$. Polazeći od toga da određivanje i strukturiranje tema u javnosti nije samo privilegij masovnih medija te da na ključne teme društvenoga života nastoje utjecati mediji, javnost, politički akteri i korporacije, definirane su četiri vrste dnevnih redova, a to su:

1) „medijski dnevni redovi (medijska agenda)

2) javni prioriteti (javna agenda)

3) prioriteti politike (politička agenda) i

4) korporativni dnevni red (korporativna agenda)“3.

Medijima se $u$ tome smislu ne pripisuje sposobnost utjecanja na to što će ljudi misliti, ali oni uvelike određuju o čemu će ljudi misliti. „Određivanje agende bitno je jer se izborom tema izvješćivanja pozornost javnosti usmjerava na određene vijesti, a mediji imaju mogućnost samostalnog izbora vijesti i tema o kojima će izvješćivati pa tako bitno utječu na društvena kretanja i usmjeravaju pažnju javnosti na određena

ŠEmSO TuCAKović, Leksikon mas-medija, Prosperitet, Sarajevo, 2004., str. 194.

Zoran Tomić, Politički odnosi s javnošću, Synopsis, Zagreb - Sarajevo, 2017., str. 429.

Zoran Tomić, Odnosi s javnošću - Teorija i praksa, Synopsis, Zagreb - Sarajevo, 2016., str. 891. -896. 
pitanja prema vlastitim kriterijima." ${ }^{4}$ Internet, a uskoro i društvene mreže, postao je dio svakodnevnoga života: „srušio je granice vremena i prostora te unio velike promjene u novinarsku struku. “5 Društvene mreže ne koriste se više samo za privatne objave i druženje, za poslovne kontakte i promociju, već sve više postaju relevantan alat za praćenje ključnih vijesti i informacija. Reutersov institut za studij novinarstva u prosincu 2016. godine u 24 zemlje svijeta proveo je istraživanje o digitalnim vijestima na uzorku od 143 osobe koje su na istaknutim pozicijama u uredništvima medija ili oglašavanju u tradicionalnim i digitalnim izdavačkim kompanijama. Kako stoji u Izvješć $u^{6}$, ljudi se sve više koriste društvenim mrežama kao izvorom vijesti, a sve manje tradicionalnim, tiskanim medijima. Studija pokazuje da se povećava broj onih koji čitaju isključivo digitalizirane vijesti te da je Facebook za gotovo polovinu ispitanika najvažniji medij za traženje, čitanje, gledanje i prosljeđivanje vijesti.

Prema istraživanju Djankova, McLiesh, Nenove i Shleifera iz 2003. godine na uzorku od 97 zemalja iz cijeloga svijeta "gotovo je u svakoj zemlji uvriježeno da su najveća medijska poduzeća u vlasništvu vlade ili privatnih obitelji“" Ovakvo razmišljanje potvrđuje sintagmu: „Tko ima medije, ima i vlast." Razvojem tehnologije razvili su se masovna komunikacija i mediji masovnoga komuniciranja koji, prema tomu, imaju izrazito veliku ulogu $\mathrm{u}$ formiranju javnoga mijenja. U tome procesu komunikacije ključnu ulogu imaju društvene mreže putem kojih publika ostaje povezana s onime što ju zanima, informacije dobivaju oni koje to zanima, a davatelj informacija zna što njegova publika želi. „Čini se da novi mediji mogu pružiti potencijalni zaokret moći od pošiljatelja prema primatelju, stvarajući puno više različitog sadržaja dostupnog

$4 \quad$ Ilija Musa, Medijsko pravo sloboda izražavanja u Bosni i Hercegovini i Republici Hrvatskoj, Školska naklada, Mostar, 2017., str. 124.

5 Dajana Šošıć, Utjecaj društvenih mreža na informativne programe javne i komercijalnih televizija, doktorska disertacija, Osijek, 2019., str. 13. - 14.

6 „Digital News Report 2017“, Reuters Institute, <https://reutersinstitute.politics.ox.ac.uk/ sites/default/files/Digital\%2oNews\%2oReport\%202017\%20web_o.pdf?utm_source=digitalnewsreport.org\&utm_medium $=$ referral $>$, (11. IX. 2019.).

7 Simeon Djankov i dr., "Who owns the media?", Journal of Law and Economics, The University of Chicago, god. XLVI. (2003.) br. 2., str. 341. - 381. 
korisnicima bez ovisnosti o sistemima masovne komunikacije. ${ }^{\text {" } 8 ~ U ~ l i p n j u ~}$ 2016. u sklopu diplomskoga rada o karakteristikama primjene društvenih mreža u medijskoj industriji u Hrvatskoj ${ }^{9}$ objavljeno je istraživanje ${ }^{10}$ koje je pokazalo da je najpopularnija društvena mreža Facebook te da se od svih korisnika društvenih mreža njih $98 \%$ koristi njime. „Od toga je 95 posto ispitanika kazalo da se njime koristi u svrhu komuniciranja, dok 82 posto preko društvenih mreža prati vijesti. ${ }^{{ }^{11}}$ Gotovo svaki drugi ispitanik društvenim se mrežama služi radi informiranja. Od ukupnoga broja ispitanika njih $65 \%$ izjasnilo se da ponekad komentira objave, no najvažnija im je aktivnost na Facebooku „lajkanje“ objava te pregledavanje videa i fotografija. ${ }^{12}$

\section{Dosadašnja istraživanja o praćenju online medija u Republici Hrvatskoj}

Agencija Ipsos provela je za medijsku kuću 24sata u siječnju 2019. godine istraživanje Medijske navike u Republici Hrvatskoj u $2019 .{ }^{13} \mathrm{kojim}$ su potvrdili trendove i dominaciju interneta koji nezaustavljivo raste. Još 2017. internet je prestigao televiziju u mjerenju percepcije pouzdanosti kao izvora kojemu se najviše vjeruje, a ovo istraživanje potvrdilo je da je internet glavni izvor informacija za $78 \%$ ispitanika te medij koji i mladi i stari najviše prate tijekom cijeloga dana. Osim toga, njih 87,7 \% tvrdi kako im pruža jedinstvene informacije koje nigdje drugdje nisu

8 Domagoj Bebić - Marija Volarević, „Viral journalism: The rise of a new form“, $M e$ dijska istraživanja: znanstveno-stručni časopis za novinarstvo i medije, Zagreb, god. xxII. (2016.) br. 2., str. 107. - 126.

9 Usp. MiA BEDNAž, „Društvene mreže u novinarstvu: karakteristike komunikacije novinara i publike putem službenih Facebook stranica novinara 24sata", diplomski rad, Sveučilište u Zagrebu, Fakultet političkih znanosti, 2017. <https://repozitorij.fpzg.unizg.hr/islandora/ object/fpzg\%3A329/datastream/PDF/view>, (27. vII. 2019.).

10 Usp. SANJin KovaČEvić, „Primjena društvenih mreža u medijskoj industriji“, diplomski rad, Sveučilište u Zagrebu, Ekonomski fakultet, 2016., <https://urn.nsk.hr/urn:nbn:hr:148:768440>, (12. VIII. 2019.).

${ }_{11} \quad$ Isto, str. 46.

12 Usp. isto, str. 30.

${ }^{13}$ Usp. „Medijske navike u Republici Hrvatskoj, Istraživanje agencije IpsosConnets za 24sata“, 24sata.hr, 2019., <https://showcase.24sata.hr/2019_hosted_creatives/medijske-navike-hr-2019.pdf>, (4. vII. 2019.). 
dostupne. Internet se najčešće koristi za elektroničku poštu, a zatim za traženje aktualnih i korisnih informacija (više od 80 \% ispitanika). Sljedeće česte aktivnosti jesu komunikacija putem Messengera i posjećivanje društvenih mreža (79,5 \%). „YouTube je prva mreža po broju korisnika (92,7 posto), ali prema vremenu koje korisnici dnevno provedu na mreži prvo mjesto zauzima Facebook (koristi ga 84,7 posto osoba, 24,6 posto više od dva sata). $S 44,8$ posto osoba koje ga koriste, Instagram je treća društvena mreža prema popularnosti. Profil na LinkedInu i Pinterestu ima oko četvrtinu korisnika interneta (25,5 posto, 24,1 posto). ${ }^{{ }_{14}}$ Twitterom se koristi svaki peti, a Snapchatom svaki deseti korisnik interneta, otkrilo je ovo istraživanje. ${ }^{15}$

Potvrđeno je da je internet medij koji u Hrvatskoj najviše utječe na kupce, bilo da se radi o odluci o kupnji, detaljnome informiranju o proizvodu ili stvaranju općega dojma o brendu. Utjecaj reklama na televiziji i u tiskanim medijima izjednačen je kod stvaranja dojma o brendu. Kod konačne odluke o kupnji i detaljnoga informiranja o proizvodu klasične reklame su, nakon interneta, drugi ključni izvor informacija, dok je TV na trećem mjestu. Božo Skoko upozorava kako elektroničke inačice tiskanih dnevnika Večernjega i Jutarnjega lista odudaraju od ozbiljnosti kojoj teže u tiskanim izdanjima jer su „na to primorani kako bi većim brojem klikova privukli oglašivače koji odlaze na čitanije portale, bez obzira na njihovu vjerodostojnost. (...) Dapače, zabilježen je pad čitanja dnevnih novina na štetu rasta čitanja novinskih portala, a čak za vrijeme gledanja televizije često se 'surfa' mobitelom. ${ }^{\text {“16 }}$

Televizijski novinar Damir Matković ustvrdio je da su „novi mediji povećali dostupnost programa, ali nisu znatnije utjecali na povećanje prihoda TV kuća, odnosno na novim medijima mnogo više zarađuju

$14 \quad$ Isto, str. $17 \cdot-18$.

15 Usp. isto, str. 18.

16 Božo Sкоко - Nikola VRdoljaK, „Stvarni dosezi news portala - međuodnos čitanosti, vjerodostojnosti i utjecaja“, Hum: časopis Filozofskog fakulteta Sveučilišta u Mostaru, Mostar, god. XIII. (2018.) br. 19., str. 80. -82 . 
tvrtke specijalizirane za mrežnu distribuciju sadržaja (online streaming) nego televizijske kompanije. ${ }^{{ }_{17}}$

Matković navodi da je razvoj digitalne tehnologije omogućio distribuciju sadržaja koji su lako dostupni u različitim oblicima: onlinestreaming radijskih i televizijskih programa, online oglašavanje i društveni mediji. ${ }^{18}$

Internet je omogućio i uvođenje interaktivnih usluga u realnom vremenu. Kako bi nove usluge postale dostupne gledateljima, televizijske se tvrtke povezuju s telekomunikacijskim kompanijama koje raspolažu infrastrukturom za distribuciju tih novih usluga. (...) Proizvodnja informativnog programa je vrlo skupa pa TV tvrtke dio troškova nastoje podmiriti eksploatacijom vijesti na digitalnim platformama. No, najveći dio zarade ide telekomunikacijskim kompanijama, a ne TV tvrtkama. ${ }^{19}$

Ključne su odlike online novinarstva hiperprodukcija tekstova, interaktivnost i multimedija te su usmjerile novinarstvo prema novomu obliku iskorištavanja ovih potencijala, dok funkcija klasičnoga novinarstva u smislu prikupljanja, obrade i raznošenja informacija postaje periferna.

Razlike u poimanju tradicionalnog i suvremenog online novinarstva toliko su velike da ranija istraživanja o online novinarstvu sugeriraju kako su sadržaji informativnih portala najmanje kreirani u redakciji, odnosno da su njihovi kreatori pojedinci i interesne grupe, pripadnici online zajednice na društvenim mrežama, globalni i lokalni mediji, novinske agencije te najvećim dijelom industrija odnosa s javnošću. ${ }^{20}$

U takvim uvjetima pozicija medija na tržištu određena je kreiranjem vlastitoga identiteta u online okruženju, bez granica. Najšira definicija

${ }_{17}$ Damir Matкović, Televizijski program - proizvodnja, dobavljači, žanrovi, Školska knjiga, Zagreb, 2019., str. 116.

18 Usp. isto, str. 116.

$19 \quad$ Isto, str. 116. - 117.

20 Andrea Wagemans - Tamara Witschge - Mark Deuze, „Ideology as Resource in Entrepreneurial Journalism: The French online news startup Mediapart", Journalism Practice, Taylor \& Francis, god XI. (2016.) br. 2., str. 160. - 177., <https://www.tandfonline.com/doi/ full/10.1080/17512786.2015.1124732>, (22. VIII. 2019.). 
prirode interneta kao novoga medija ona je francuskoga politologa i filozofa Francisa Ballea, prema kojoj je riječ o „univerzalnom mediju, istovremeno uni-mediju i višemediju: o jedinstvenom nosaču vrlo različitih programa, kako po sadržaju, tako i po načinu korištenja, ovisno o mogućnosti ljudske mašte. ${ }^{{ }_{21}}$ Kao ključne osobine izdvaja raznolikost, i po sadržaju i po izvoru, globalnu rasprostranjenost i povezanost po hypertext principu, ogromnu količinu bez mogućnosti potpune kontrole sadržaja jer su neki sadržaji pristrani, sami sebi svrhom, propagandni, promotivni, neki su sadržaji slučajno netočni (faktor pogreške), a neki namjerno netočni, fake news.

Većina online vijesti jako je slična vijestima iz tradicionalnih medija, ali ima primjesu nekih specifičnosti, primjerice spajanje profesionalnosti i domišljatosti novinara jer nije lako ostvariv cilj postati primijećen u online svijetu. Dok tradicionalan način pisanja leada ${ }^{22}$ (glave vijesti) podrazumijeva sadržaj udarne vijesti sveden na odgovore na šest pitanja: Tko?, Što?, Gdje?, Kada? Kako? i Zašto?, za online medije lead se mora pisati tehnikom obrnute piramide, gdje se piše sažeto i rječito, a činjenice redaju od najvažnije do najmanje važne. „Da bi se informacije organizirale na ovaj način, online novinar mora odlučiti koji su elementi najvažniji za objavu. Obrnuta piramida navodi novinara na razmišljanje o stupnjevanju važnosti informacija, stoga se one najvažnije nalaze na početku kako bi čitatelja informirale i zaokupile mu pozornost. ${ }^{{ }_{23}}$

Tradicionalan način pisanja vijesti i rada na desku u informativnoj redakciji podrazumijeva predstavljanje informacije javnosti u potpunosti, točno i po smislenome redu, koju će publika pratiti od početka do kraja. Online novinarstvo sasvim je drugačiji koncept pisanja priče. „Dodavanjem linkova $\mathrm{k}$ vanjskim informacijama većina $w e b$-stranica postaje višesmjerna - potiče vas da sami određujete put, da se zadržite na jednom

${ }_{21} \quad$ Francis Balle, Moć medija, mandarin i trgovac, Clio, Beograd, 1997., str. 75. - 76.

${ }^{22}$ Leadom ili sažetkom nazivamo uvodni odlomak vijesti (prva dva-tri retka teksta). Ponekad se taj odlomak još naziva glavom ili napadom vijesti. To je nesumnjivo najvažniji dio agencijske vijesti jer predstavlja njezin sažetak, kratak sadržaj bitnih informacija napisan sa što manje riječi. Lead je u idealnome slučaju tekstualna cjelina koja može ostvariti informativnu funkciju samostalno, koja je iskoristiva kao takva i neovisna o ostatku vijesti.

${ }^{23}$ Mato Brautović, Online novinarstvo, Školska knjiga, Zagreb, 2011., str. 153. - 170. 
aspektu priče i o njemu pročitati nešto više. ${ }^{{ }^{24}}$ Stamenković zaključuje kako publika na ovaj način ulazi u interakciju s online informacijom i nema sigurna vodiča u profesionalnome novinaru, već je sam sebi vodič kroz tekst. Tkalec i Krušelj upozoravaju kako u svim medijima, a posebno na portalima, prevladava stav da je vijest najvažnije objaviti, a tek onda profesionalno dotjerati. „Važno je imati informaciju, kako ne bi kasnili za ostalima, a tek zatim slijedi dotjerivanje i lektoriranje teksta, dopisivanje novo prikupljenih detalja, analitičko produbljivanje teme i stavljanje popratnih vizualnih podloga. ${ }^{{ }^{25}}$ Novinarstvo se, unatoč svojoj otvorenosti, smatra odgovornom djelatnošću jer utječe na organizacije, zajednicu i pojedince. „U novinarstvu bi to mogle biti određene vrijednosti, poput istine, potpunosti, pravodobnosti i jasnoće te pojedini etički principi. Dakle, novinar ili urednik su, na primjer, odgovorni za istinitost neke priče, poštovanje privatnosti ili čuvanje tajnosti izvora. ${ }^{{ }{ }_{2}}$

\section{Društvene mreže}

Definirane kao mjesta susreta, kreiranja i komunikacije, s prilagodljivim komunikacijskim tehnikama i sve većom dostupnošću interneta, društvene mreže poput Facebooka, Twittera i ostalih bitno su promijenile način komunikacije između organizacija, zajednica i pojedinca pretvaranjem komunikacije $\mathrm{u}$ interaktivni dijalog. ${ }^{27}$

Jedno od osnovnih pravila u dobroj novinarskoj praksi jest provjeriti svaku informaciju prije objavljivanja i navesti njezin izvor. Vjerodostojnost društvenih mreža kao izvora informacija uvijek se potvrđuje dodatnim izvorima. Nije autentično i sukladno novinarskoj praksi oblikovati vijest na temelju jedne e-pošte, objave na društvenim mrežama ili posta na blogu. Ti materijali mogu biti vrijedan izvor za priču, no takvu infor-

${ }_{24}$ SlaĐANa Stamenković, „Novinarstvo i mediji budućnosti - kreiranje identiteta i stvarnosti“, In medias res : časopis filozofije medija, Zagreb, god. IV. (2015.) br. 6., str. 851.

25 Gordana TKalec - Željko KrušelJ, Uredništvo - koncepti uredivanja u predigitalno $i$ digitalno doba, Centar za digitalno nakladništvo, Sveučilište Sjever, 2019., str. 111.

26 Aleksandar Bogdanić, Medijska slika: istraživanja o odgovornom novinarstvu, Fakultet političkih nauka Univerziteta u Banjoj Luci, Banja Luka, 2015., str. 7.

27 Usp. Marina MuČalo - Silvio Šop, „Nova publika novih medija“, Informatologia, Zagreb, god. XLI. (2008.) br. 1., str. 53 . 
maciju treba uvijek provjeriti s autorom objave kako bi vijest dobila na vjerodostojnosti. ${ }^{28}$

Uz to, u posljednjih nekoliko godina „društvene mreže (...) su postale alternativni izvori informacija o događajima u svijetu“" ${ }^{29}$. Specifičnost je takvih vijesti u tome da ih istovremeno saznaju i korisnici i novinari. „Vijesti se mogu promatrati dok se događaju - greške, netočnosti, sve. ${ }^{{ }^{30}}$ Volarević i Bebić upozoravaju da je vjerodostojnost informacija na društvenim mrežama često upitna. To je i razumljivo jer se lako može manipulirati s poviješću uređivanja, mogu se brisati statusi i objavljivati novi, bez ikakvih posljedica. Naime, ne postoji zakonski okvir koji bi isključivo regulirao komunikaciju na društvenim mrežama. „Vrijednost novinarske profesije, a time i vjerodostojnost pojedinog medija, ogleda se i u provjeravanju svake informacije iz najmanje dva izvora. ${ }^{\text {“31 }}$ No, u praksi internetski novinari često krše to temeljno načelo jer im društvene mreže prije svega služe za promociju i distribuciju sadržaja, a tek onda za novinarstvo. Žlof, Herljević i Hadžić kao pozitivne strane društvenih mreža ističu brzinu širenja informacija, mogućnost besplatne promidžbe proizvoda i vlastitih tekstova, razmjenu mišljenja, stavova i vrijednosti s drugima te čitateljevu povratnu informaciju. ${ }^{32}$ Kao negativne, zabrinjavajuće strane ističu prenošenje vijesti iz neprovjerenih izvora, manipuliranje i objavljivanje sadržaja koji nemaju nikakve veze s novinarstvom. ${ }^{33}$ Također, moguće je i da neki portali namjerno putem

28 Marija Volarević - Domagoj Bebić, „Društvene mreže kao izvor vijesti u najgledanijim središnjim informativnim emisijama u Hrvatskoj", Medijske studije, Zagreb, god. Iv. (2013.) br. 8., str. 63 .

${ }_{29}$ Zrinjka PerušKo, Uvod u medije, Hrvatsko sociološko društvo - Naklada Jesenski i Turk, Zagreb, 2011., str. 182.

3o Richard Rudin - Trevor Ibbotson, Uvod u novinarstvo: Osnovne tehnike i temeljna znanja, Mate, Zagreb, 2008., str. 111.

31 Adriana Tomašić, „Vjerodostojnost medijskih objava na javnome radiju“, MediAnali: međunarodni znanstveni časopis za pitanja medija, novinarstva, masovnog komuniciranja $i$ odnosa s javnostima, Dubrovnik, god. IV. (2010.) br. 7., str. 127. - 138.

32 Usp. Ksenija Žlof - Zlatko Herljević - Slobodan Hadžić, „Predodžbe novinara o važnosti društvenih mreža u proizvodnji medijskih sadržaja", Media, culture and public relations, Zagreb, god. v. (2013.) br. 1., str. 27.

${ }_{33}$ Usp. isto, str. 25. 
društvenih mreža objavljuju informacije bez provjere, radi nekih interesa ili podizanja prometa posjećenosti. Žlof, Herljević i Hadžić ustvrdili su kako „uporabom društvenih mreža političari nisu otvorili komunikaciju s građanima, nego samo simuliraju otvorenost te da se PR stručnjaci mudro i obilato koriste društvenim mrežama za promicanje svojih

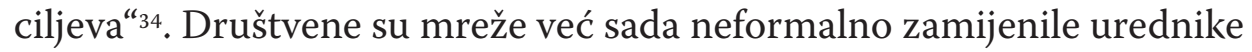
u redakcijama koji su odlučivali što će javnosti plasirati svakoga jutra. Sada se korisnici sve više obraćaju društvenim mrežama i one su im prvi, često i jedini, izvor informacija. „No, kako mediji shvaćaju kako se vrijednost ne mjeri samo u klikovima, već u angažiranosti publike, oni će nastojati iskoristiti prednosti nekih drugih platformi. ${ }^{{ }_{35}}$

Prema Zoranu Tomiću Facebook je servis za dijeljenje informacija i komunikaciju među prijateljima, a njegova je osnovna karakteristika socijalni graf - graf povezanosti među njegovim korisnicima - koji vjerno modelira društvene odnose iz stvarnoga svijeta. ${ }^{36}$ Facebook je u Hrvatskoj najpoznatija društvena mreža kojom se mediji koriste radi promocije svojega sadržaja, interakcije s korisnicima i povećanja broja sljedbenika. Korisnici imaju mogućnost ocjenjivanja sadržaja izražavanjem emocije, pisanja komentara i sudjelovanja u raspravama te prosljeđivanju toga sadržaja. Pomanjkanje mehanizama kontrole online medijskoga prostora i mogućnosti manipuliranja informacijama i porukama mogu ozbiljno ugroziti upravo pojam vjerodostojnosti, odnosno sve elemente na kojima ona počiva. Primajući nagradu za najboljega novinara u 2018. godini prema izboru Hrvatskoga novinarskog društva ${ }^{37}$, Hrvoje Krešić, reporter $\mathrm{N}_{1}$ televizije u Hrvatskoj, samokritički se osvrnuo na stanje u medijima te rekao da smatra da su pojavom interneta i tehnoloških giganata poput Googlea i Facebooka, kojima tradicionalni mediji doslovce

$34 \quad$ Isto, str. 27.

35 Vadim Lavrus, "The Future of Social Media in journalism“, Mashable, 2010., str. 62. <https://mashable.com/2010/o9/13/future-social-media-journalism/?europe=true>, (14. VII. 2018.).

${ }^{36}$ Usp. Zoran Tomić, Politički marketing - načela i primjena, Sveučilište u Mostaru Synopsis, Mostar - Zagreb - Sarajevo, 2014., str. 472.

37 Usp. Ivica Buljan, „Intervju - Hrvoje Krešić: novinarski posao mora se raditi profesionalno i u dobroj vjeri", Hrvatsko novinarsko društvo, <https://www.hnd.hr/intervju-hrvoje-kresic-novinarski-posao-mora-se-raditi-profesionalno-i-u-dobroj-vjeri>, (17. x. 2018.). 
daruju svoj sadržaj, spinovi iz političkih i gospodarskih krugova zagospodarili naslovnicama. „U takvoj situaciji, u takvom modelu, novinari i urednici nužno moraju postati dijelom establišmenta, biti bliski onima koji donose odluke i plasiraju spinove, ne zamjeriti se izvoru svojih 'ekskluziva.' A kada to novinari postanu, onda sigurno ne vode primarno računa o svojim čitateljima i njihovim problemima, nego o problemima donositelja svojih 'ekskluziva'" ${ }^{38}$.

Ekonomska neizvjesnost i politički pritisci razlozi su zbog kojih novinari odustaju od profesionalnih standarda, pa „zemlje u kojima je stupanj medijskih sloboda na nižem nivou i u kojima je novinarstvo manje nezavisno i profesionalno, imaju visoku razinu korupcije ${ }^{{ }_{39}}$. Pritisci poslodavaca, indirektno države i političkih elita, te oglašivača koji financiraju izdavače nužno vode autocenzuri i odustajanju od profesionalizma i osnovnih načela novinarske etike. Profesionalno i vjerodostojno novinarstvo sve se više povlači pred tabloidnim i senzacionalističkim jer zabavni, trivijalni i spektakularni sadržaji dominiraju nad informacijama i temama koje su javno važne, a novinari, kako ih je definirao Danko Plevnik u knjizi Praksa etičkog novinarstva, postaju „medijski agenti političko financijskog osiguranja svoje medijske kuće“" ${ }^{40}$. Bivši glavni urednik vodećih britanskih dnevnih novina Jason Seiken ustvrdio je da se uloga urednika u online medijima drastično promijenila.

Postoje na web-u mnogo precizniji alati od uredničkog osjećaja koji govore o tome koje priče birati i kakve efekte donose svojim radom pojedini novinari, a da bi imali veće efekte po oglašivače, novinari i urednici ne mogu se ponašati izolirano u odnosu na medijski biznis i ne mogu ne poznavati mehanizme o kojima ovisi hoće li se i kako oglašivači pojaviti u sklopu online medija. Poštujući uređivački integritet, novinari su ti koji bi trebali utjecati na veći angažman čitatelja. ${ }^{41}$

38 Isto.

39 Stephan Russ-Mohl, Danas, dnevni list, Beograd, 13. XII. 2014.

40 Danko Plevnik, Praksa etičkog novinarstva: (deset zakrvavljenih godina), Masmedia, Zagreb, 2003., str. 127.

${ }^{41}$ Temeljna istraživanja o novinarstvu u doba interneta dostupna su na portalu NL Nieman Journalism Lab, projektu posvećenomu traganju za odgovorima na pitanja: Što budućnost donosi medijima? i Kako se mijenja novinarstvo? Između ostaloga, 2014. godina posvećena 


\section{Objave news portala na društvenoj mreži Facebook}

Deset news portala: 24sata.hr, DNEVNIK.hr, Dnevno.hr, HRT Vijesti, Index.hr, Jutarnji.hr, Net.hr, Tportal.hr, Večernji.hr $i$ VIJESTI.hr u četiri dana u rujnu 2019. godine objavilo je na Facebooku 2680 objava i statusa. ${ }^{42}$ Objave svih deset portala obrađene su u roku od 48 sati nakon posljednje objave u praćenome danu. Najviše objava imao je portal Index.hr, a najmanje HRT Vijesti. Rezultati broja objava news portala na društvenoj mreži Facebook pokazuju kako su najaktivniji komercijalni pružatelji elektroničkih publikacija, a tek potom mrežne stranice u vlasništvu novinskih nakladnika i komercijalnih televizija s nacionalnom koncesijom. Portal Hrvatske radiotelevizije je među najmanje aktivnim portalima na Facebooku. Prosječno u dva sata imaju po jednu objavu, dok vodeći Index.hr u jednome satu ima u prosjeku osam objava.

Tablica 1. Broj objava svakoga portala na Facebooku

\begin{tabular}{|l|l|}
\hline Medij & Učestalost \\
\hline 24sata.hr & 178 \\
\hline DNEVNIK.hr & 202 \\
\hline Dnevno.hr & 353 \\
\hline HRT Vijesti & 50 \\
\hline Index.hr & 771 \\
\hline Jutarnji.hr & 239 \\
\hline Net.hr & 232 \\
\hline Tportal.hr & 279 \\
\hline Večernji.hr & 174 \\
\hline VIJESTI.hr & 202 \\
\hline
\end{tabular}

Rezultati pokazuju kako objave news portala s društvenih mreža kod većine portala nestaju 7 - 10 dana nakon što su bile objavljene. Postoje tri moguća razloga:

je istraživanju društvenih medija. <http://www.niemanlab.org/2014/12/complicatingthe-network-the-year-in-social-media-research/> (12. I. 2016.).

${ }^{42}$ Pristup analitičkoj matrici kreiranoj preko Google Docsa dostupan: <https://docs.google.com/spreadsheets/d/1qXLe4XViNiRoDph76wfKVQruOHF1WYMqHXB7IDbIzvs/ edit\#gid=o $>$. 
1) Uredništva ih sama brišu jer neki statusi nisu postigli željenu količinu reakcija, komentara i dijeljenja pa time smanjuju dosege samoj stranici i buduće objave automatski mogu imati manju vidljivost.

2) Uredništva ih sama brišu jer su pod određenim pritiskom sama uklonila i objavu na portalu.

3) Facebook ih sam sklanja sa sučelja profila news portala zbog serverskih resursa.

Većina objava ostane dostupna preko Facebookove tražilice, ali korisnik mora točno znati koji status ili objavu traži. Nakladnici elektroničkih publikacija nisu dužni moderirati komentare ispod statusa koje su objavili njihovi pratitelji, ali to redovito čine kada primijete govor mržnje, netoleranciju, zlostavljanje, zastrašivanje, poziv na linč ili vrijeđanje te ako dobiju sudski nalog. „Komentari na Facebooku nisu urednička odgovornost već odgovornost društvene mreže iako je Vlada RH najavljivala donošenje Zakona o nedopuštenom ponašanju na internetu s ciljem da se to promijeni i da se zbog komentiranja na društvenim mrežama utvrđuje urednička i osobna odgovornost pojedinaca." ${ }^{43}$ Specifičnost online novinarstva postale su native objave koje se pišu u skladu s uredničkim smjernicama, sponzorirane su i služe za promociju osoba, novih proizvoda, trendova, društvenih događaja, zanimanja, obrta ili tvrtki. Portali na taj način nadoknađuju nedostatak prihoda od digitalnoga marketinga, ali kako u tim člancima nema kritičkoga odmaka, oni primatelje informacija mogu dovesti u zabludu, što je neetično i suprotno članku 2. stavku 17. Zakona o elektroničkim medijima. ${ }^{44} \mathrm{Naj-}$ veći broj promotivnih tekstova u promatranome razdoblju objavio je portal DNEVNIK.hr na svome profilu na Facebooku. Od 202 objave njih 43 imaju karakteristike promotivnih objava, od kojih njih 37 odnosno

43 „Izjava za medije ministrice kulture Nine Koržinek Obuljen“, Hina, 2019., <https://vlada. gov.hr/vijesti/obuljen-korzinek-regulirat-cemo-odgovornosti-za-nedopusteni-govor-mrznje-u-medijima-i-na-drustvenim-mrezama/25097>, (20. x. 2019.).

44 Usp. "Zakon o elektroničkim medijima“, Narodne novine, 2013., 94., čl. 2., st. 17., <https:// www.zakon.hr/z/196/Zakon-o-elektroni\%C4\%8Dkim-medijima>, (15. X. 2019.). 
18 \% nema istaknutu napomenu da se radi o mogućem marketinškom članku.

Tablica 2. Broj objavljenih promotivnih članaka svih portala na Facebooku

\begin{tabular}{|l|l|l|}
\hline Kategorije & Učestalost & Postotak \\
\hline $\mathrm{Da}$ & 23 & 1 \\
\hline $\mathrm{Da}$, ali bez istaknute oznake & 124 & 5 \\
\hline $\mathrm{Ne}$ & 2533 & 95 \\
\hline
\end{tabular}

Ovakva intenzivna učestalost promotivnih članaka može se tumačiti činjenicom kako je Dnevnik Nove TV najgledanija emisija na svim nacionalnim televizijama te da se Nova TV kao vlasnik televizije i nakladnik portala DNEVNIK.hr koristi tom sinergijom svojih medija za povećanje prihoda od oglašivačke industrije.

Istraživanje potvrđuje da su na Facebookovim stranicama vodećih hrvatskih dnevnoinformativnih internetskih portala najzastupljeniji sadržaji vezani za zabavu i šoubiznis, sport, a potom politiku, životni stil i crnu kroniku. Vrlo su malo zastupljeni sadržaji vezani za pravosuđe, vanjsku politiku, gospodarstvo, znanost i školstvo te vremensku prognozu. Internetsku publiku većinom čine osobe mlađe životne dobi, koje traže zabavne i relaksirajuće sadržaje, pa se može pretpostaviti da se sadržaji objava prilagođavaju ukusu publike. Ovakav rezultat ukazuje na to da portali podilaze publici i podržavaju trend opće medijske komercijalizacije sadržaja naglašavajući područja lake zabave i relaksacije na štetu relevantnih problema pojedinaca i društva. Po broju objava u rubrici „Showbiz i zabava” prednjače komercijalni portali Net.hr, Večernji.hr, 24sata.hr i DNEVNIK.hr te svaka treća odnosno svaka četvrta objava dolazi iz te rubrike. Na Facebookovim stranicama portala Index. $h r$ i Tportal.hr dominiraju objave iz rubrike "Sport” s 27 odnosno 26 \%. Jedino HRT Vijesti, Dnevno.hr i Jutarnji.hr na Facebooku objavljuju dominantno političke vijesti. Najveću učestalost takvih vijesti, $36 \%$, ima javni servis - HRT Vijesti. 


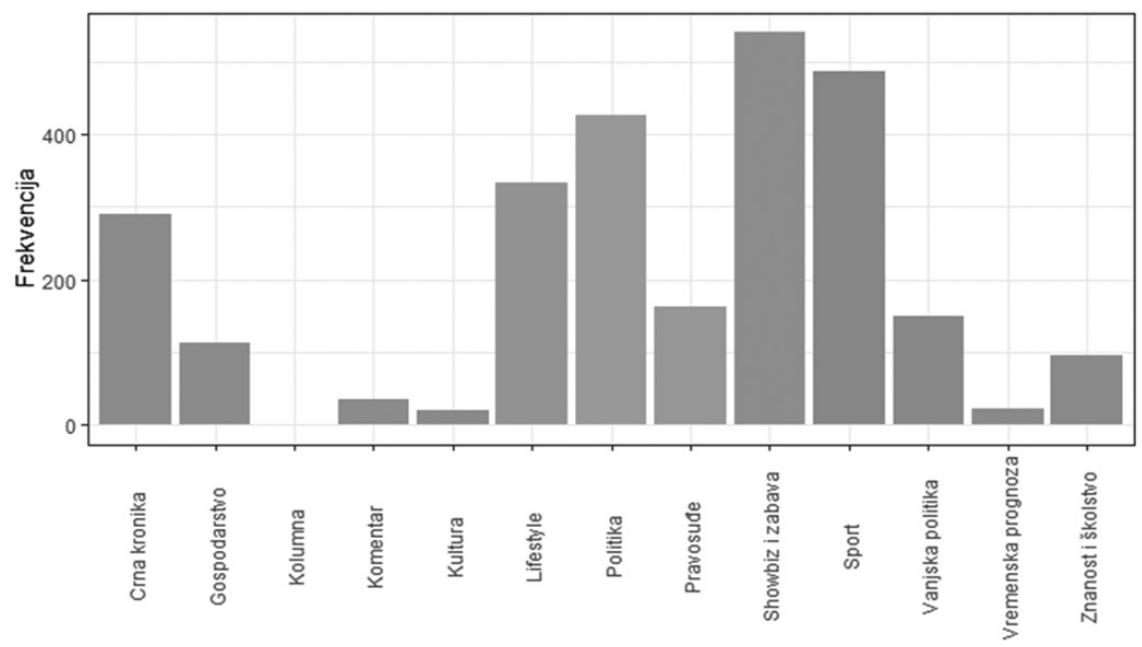

Grafikon 1. Učestalost objava po rubrikama - svi portali

Istraživanje je potvrdilo kako redakcije u svakome trećem napisanom statusu na Facebooku iznose i vrijednosni sud, a u broju vrijednosnih sudova prednjače komercijalni portali skloni senzacionalizmu i žutilu poput portala Dnevno.hr. Vrijednosnih sudova nema ili su izrazito rijetki u statusima urednika portala DNEVNIK.hr, HRT Vijesti i VIJESTI.hr čiji su nakladnici nacionalne televizije. 24sata.hr, Večernji.hr i Tportal prednost daju neobojenoj informaciji.

Tablica 3. Broj objava dezinformacija ili lažnih vijesti na Facebooku

\begin{tabular}{|l|l|l|}
\hline Kategorije & Učestalost & Postotak \\
\hline $\mathrm{Da}$ & 3 & 0 \\
\hline $\mathrm{Ne}$ & 2675 & 100 \\
\hline
\end{tabular}

Istraživanje je potvrdilo da se u pisanju statusa komercijalni portali najviše služe tehnikama manipulacija u kojima iznose vrijednosne sudove ili sugestije s ciljem stvaranja dojma ili povećanja broja klikova clickbaiting metodom. Najveći broj manipulativnih statusa kreira Dnevno. $h r(42 \%)$, a visok postotak imaju i Net.hr (33\%), Index. hr (22\%) i Jutarnji. $h r(26 \%)$. Portali svih triju televizija s nacionalnom koncesijom DNEVNIK.hr, HRT Vijesti i VIJESTI.hr nisu imali elemenata manipulativnih 
statusa u svojim objavama. Ovo su primjeri nekih statusa: donosimo, pogledajte, otkrivamo, ovako nešto još niste vidjeli, ovo se isplati pročitati, nije mu lako, Plenković puca, nije tako bezazleno, kakva drama, slijede novi problemi, totalni kaos, poremećeni idiot, oštar kao i uvijek, otkrio neke sočne detalje, prevarili ste se, stat će vam mozak, istraživanje nas je šokiralo...

Na početku, u sredini i na kraju statusa vrlo se često koriste i emojiji. Podatci potvrđuju kako korisnici društvenih mreža najviše reagiraju („lajkaju“) na životne priče i teme o stilu života, sportske vijesti, prognozu vremena, zabavu pa tek onda politiku. Najuspješniji su u tome komercijalni portali Net.hr, Večernji.hr, DNEVNIK.hr, 24sata.hr i Index. $h r$. Najviše se, pak, komentiraju vijesti koje progovaraju o društvenim i socijalnim nepravdama, nefunkcioniranju institucija, glomaznome, a nefunkcionalnome državnom aparatu, za što se uvijek proziva aktualna politička garnitura. Takve vijesti moraju biti autentične, vizualno atraktivne i sadržajno životne kako bi se čitatelj mogao poistovjetiti s osobom ili događajem o kojem se piše ili prisjetiti svojega sličnog iskustva.

Tablica 4. Broj objava na Facebooku s najvećim brojem komentara - svi portali

\begin{tabular}{|l|l|l|l|}
\hline Datum & Medij & Broj komentara & Rubrika \\
\hline 5.9. 2019. & Jutarnji.hr & 1005 & Crna kronika \\
\hline 5.9. 2019. & Večernji.hr & 343 & Politika \\
\hline 5.9. 2019. & 24sata.hr & 870 & Politika \\
\hline 5.9. 2019. & DNEVNIK.hr & 1813 & Showbiz i zabava \\
\hline 12.9.2019. & Dnevno.hr & 200 & Politika \\
\hline 12.9.2019. & HRT Vijesti & 1029 & Politika \\
\hline 12. 9.2019. & VIJESTI.hr & 161 & Politika \\
\hline 12.9.2019. & Net.hr & 1482 & Showbizi zabava \\
\hline 26. 9.2019. & Index.hr & 2836 & Politika \\
\hline 26. 9.2019. & Tportal.hr & 64 & Pravosude \\
\hline
\end{tabular}

Najveći broj dijeljenja, 632 puta, imala je objava podijeljena na Facebookovoj stranici HRT Vijesti 12. rujna 2019. godine. Iz arhive Hrvatske radiotelevizije sharean je video Anketa o ravnopravnosti žena, 1980. 
Svi portali na društvenim mrežama objavljuju vijesti koje su saznali na društvenoj mreži, bez kritičkoga odmaka. Također, spremno preuzimaju agencijske vijesti, ali ih opremom i izborom fotografije pretvaraju u senzacionalističke objave, najčešće preuveličavajući istinu i potvrđujući kako im je od informiranja javnosti važniji broj klikova. Primjer takve prakse jest objava portala Net.hr u kojoj prenose agencijsku vijest Hine o pripadnicima HOS-a. ${ }^{45}$

Uočeno je iskorištavanje negativnih vijesti za generaliziranje stanja i pretvaranje osobnih dojmova pojedinaca u opće nezadovoljstvo javnosti. Primjerice, usred turističke sezone plasirana je vijest o lošem iskustvu gostiju hotela na moru - bez konkretna slučaja, imenovana izvora informacije i kritičkoga odmaka od takve vijesti. Umjesto da su izuzeti hotelijeri koji profesionalno i kvalitetno rade svoj posao, što u recenzijama potvrđuju brojni gosti, svrstani su među one koji iskorištavaju goste. ${ }^{46}$

U objavama se često kao jedini izvor informacije nalaze fotogalerije, linkovi s drugih portala ili društvenih mreža. Nema izjava aktera događaja, ali novinar spremno interpretira viđeno i umjesto šire informacije nudi reciklažu vijesti iz nekih prošlih objava. Većina portala međusobno se poštuje, što se može zaključiti po korektnome prenošenju vijesti od konkurencije uz navođenje izvora informacija i stavljanja poveznice.

Istraživanje je potvrdilo kako su vijesti iz crne kronike među onima koje izazivaju najviše reakcija društvene zajednice. Zanimljivo je da portali takve vijesti vrlo često preuzimaju od lokalnih portala koji imaju mrežu dojavljivača i dopisnika i u njima nema izjava policije, ali ni informacije je li novinar pokušao doći do službene informacije, pa

45 Usp. „SJEĆATE SE OVOG ČOVJEKA? On i njegova ekipa danas su opet paradirali pod parolom 'za dom spremni'", Net.hr, <https://net.hr/danas/hrvatska/sjecate-se-ovog-covjeka-on-i-njegova-ekipa-danas-su-opet-paradirali-pod-parolom-za-dom-spremni/?fbclid=IwAR2 KTHCFZdlim7aoZGuKL81pkkw2 Q4 GrlMrnLATZBOk 3 DGDI7V8OBmdEk18>, (14. VII. 2018.).

46 Usp. „PRLJAVE TAJNE HOTELA NA MORU: I kad vam soba izgleda čisto - nije! Šokirat će vas koliko često peru posteljinu“, Net.hr, <https://net.hr/magazin/putovanja/prljave-tajne-hotela-na-moru-i-kad-vam-soba-izgleda-cisto-nije-sokirat-ce-vas-koliko-cesto-peru-posteljinu/?fbclid=IwAR3dfPdFwu5MpaGSKgOWHnvHVYHG41aqwxF82hH1XKRZX6bgffurVR 3 XVqM>, (14. VII. 2018.). 
se objave temelje na izjavama svjedoka, preživjelih ili na interpretaciji fotografija. U izvješćivanju o pravosudnim predmetima izostavlja se institut presumpcije nevinosti pa se tako već u naslovima tvrdi „da su počinili štetu" umjesto da se izrazi sumnja u počinjenje štete, što bi bilo profesionalnije i korektnije izvještavanje.

Iako news portali imaju naviše pratitelja na društvenim mrežama, brojne objave prolaze bez ikakve reakcije pa neke objave ponavljaju. Primjer je portal DNEVNIK.hr koji je objavu ${ }^{47}$ sestrinskoga portala $z a-$ dovoljna.hr o bikiniju top-modela ponovio dva puta u tri sata. Iako se Večernji.hr trudi na društvenim mrežama biti vjerodostojan i relevantan, često se koristi tehnikom clickbaitinga, a jedan od takvih teksto$\mathrm{va}^{48}$ nema ni potpisana autora ni izvora informacija, iako su one više puta znanstveno dokazane. Istraživanje je potvrdilo kako oglašivačka industrija utječe na uredničku politiku, a najočitiji je dokaz toj tezi objava Tportala na Facebooku kako „Pevec otvara retail park u Vukovaru“. Iako se radi o klasičnoj PR objavi, informacija nije označena kao plaćena objava ili oglas. ${ }^{49}$

Kvaliteta pisanja i izražavanja novinara, posebno u pisanju statusa na društvenim mrežama, zabrinjavajuća je. Osim nedovršenih rečenica i nedorečenih izjava, piše se i nestandardnim hrvatskim jezikom, a novinari, iako dolaze iz etabliranih redakcija, ne poznaju osnove gramatike pa u statusima pišu: biti će, obečavajuće, hapšenje, pljačka i sl.

47 Usp. „Prestara si za to': Fotografija u bikiniju slavne dame koja je podijelila društvene mreže", Zadovoljna.hr, <https://zadovoljna.dnevnik.hr/clanak/prestara-si-za-to-fotografija-u-bikiniju-slavne-dame-koja-je-podijelila-drustvene-mreze---570892.html?fbclid=IwARoVsdXdaJeUaA9UxlmSiMV5SAnQBapOm9zZCdqUA1Ib-9TulndzcEgH5es>, (14. VII. 2018.).

48 Usp. „Namirnice koje biste trebali jesti nakon 40. godine“, Večernji.hr, <https://www.vecernji. $\mathrm{hr} /$ lifestyle/namirnice-koje-biste-trebali-jesti-nakon-40-godine-13378o2? utm_source=Facebook\&utm_medium $=$ Status\&utm_content $=1337802 \& u t m \_$campaign $=F B+$ page + statu si\&fbclid=IwAR1WKmVWEFJHIN 3 eNeT-CTLqlzhO4Xp7EAkRoUK1DYlxoeS2 WrfdDnEa8Hc>, (14. VII. 2018.).

49 Usp. „Pevec otvara retail park u Vukovaru“, Tportal.hr, <https://www.tportal.hr/biznis/clanak/pevec-otvara-retail-park-u-vukovaru-20190808?utm_source=facebooktportal\&utm _ medium=fanpagetportal\&utm_campaign=facebookshare\&fbclid=IwAR2Ic3u4FEsy17 RJVVyhSej_ejcuDtZqZZ_UnANhxrYsSQESVtg--3kAUHw>, (14. VII. 2018.). 


\section{Zaključak}

Popularnost društvenih mreža omogućila je novinarima i urednicima elektroničkih publikacija još jedan kanal za plasiranje već pripremljenih sadržaja koji mogu imati globalni doseg za vrlo malu cijenu te virtualno neograničen prostor. Cijena medijskoga sadržaja ostala je ista, no zbog konkurencije sveprisutno je prevođenje i prilagodba sadržaja s inozemnih i domaćih medija - copy-paste novinarstvo. Ipak, mogućnosti novinarstva nisu nikad bile bolje jer novinari na raspolaganju imaju brojne tehnike i alate za prikupljanje, obradu i brzu objavu informacija. Nepostojanje održivih poslovnih modela i bitka za svaki oglas ili PR objavu online novinarstvo prisiljavaju na distribuciju sadržaja koji nije u skladu s etičkim načelima, već $s$ načelima društvenih mreža na kojima su dosezi objava, broj komentara i lajkovi postavljeni kao mjerilo za novinarstvo. Ovaj rad potvrdio je da su društvene mreže ključni kanal komunikacije news portala s pratiteljima, ali i važan izvor informacija korisnicima društvenih mreža te samim novinarima, koji vrlo često izvore informacija svojih tekstova temelje upravo na objavama s društvenih mreža. Zbog takve prakse online novinarstvo bi u budućnosti moglo postati prvi izvor informacija u Hrvatskoj. Plaćene objave portala na društvenim mrežama služe isključivo kao sredstvo za povećavanje dosega plasiranoga sadržaja, brendiranje portala, a time i utjecaja u javnosti koji je presudan za privlačenje digitalnoga oglašavanja.

\section{Literatura}

- Balle, Francis, Moć medija, mandarin i trgovac, Clio, Beograd, 1997.

- Bebić, Domagoj - Volarević, Marija, „Viral journalism: The rise of a new form“, Medijska istraživanja, Zagreb, god. XXII. (2016.) br. 2., str. 107. - 126.

- BEDNAž, MiA, „Društvene mreže u novinarstvu: karakteristike komunikacije novinara i publike putem službenih Facebook stranica 
novinara 24sata", diplomski rad, Sveučilište u Zagrebu, Fakultet političkih znanosti, 2017.

- Bogdanić, Aleksandar, Medijska slika: istraživanja o odgovornom novinarstvu, Fakultet političkih nauka Univerziteta u Banjoj Luci, Banja Luka, 2015.

- Brautović, Mato, Online novinarstvo, Školska knjiga, Zagreb, 2011.

- Djankov, Simeon - Mcliesh, Caralee- Nenova, Tatiana Shleifer, ANDreI, "Who owns the media?", Journal of Law and Economics, The University of Chicago, god. XLVI. (2003.) br. 2., str. 341. -381 .

- KovaČIĆ, SinišA, Agencijsko novinarstvo, Visoka poslovna škola Zagreb s pravom javnosti, Zagreb, 2013.

- KovaČIĆ, SiniŠA - BARAN, TANJA, „Novi mediji - generator novih tehnika manipulacija", Hum, Mostar, god. XIII. (2018.) br. 19., str. 267. -295 .

- KovaČević, Sanjin, „Primjena društvenih mreža u medijskoj industriji“, diplomski rad, Sveučilište u Zagrebu, Ekonomski fakultet, 2016.

- Lavrus, V., The Future of Social Media injournalism, Mashable, 2010.

- MAtKović, DAmir, Televizijski program - proizvodnja, dobavljači, žanrovi, Školska knjiga, Zagreb, 2019.

- MuČalo, Marina- Šop, Silvio, „Nova publika novih medija“, Informatologia, Zagreb, god. XLI. (2008.) br. 1., str. 51. - 55 .

- Musa, Ilija, Medijsko pravo sloboda izražavanja u Bosni i Hercegovini i Republici Hrvatskoj, Školska naklada, Mostar, 2017.

- Peruško, Zrinjka, Uvod u medije, Hrvatsko sociološko društvo - Naklada Jesenski i Turk, Zagreb, 2011.

- Plevnik, Danko, Praksa etičkog novinarstva: (deset zakrvavljenih godina), Masmedia, Zagreb, 2003. 
- Rudin, Richard - Ibbotson, Trevor, Uvod u novinarstvo: Osnovne tehnike i temeljna znanja, Mate, Zagreb, 2008.

- Sкоко, Božo - VRdoljak, Nikola, „Stvarni dosezi news portala - međuodnos čitanosti, vjerodostojnosti i utjecaja", Hum, Mostar, god. XIII. (2018.) br. 19., str. 79. - 98.

- Stamenković, SlaĐana, „Novinarstvo i mediji budućnosti kreiranje identiteta i stvarnosti“, In medias res : časopis filozofije medija, Zagreb, god. IV. (2015.) br. 6., str. 838. -858.

- Šošıć, DAJANA, Utjecaj društvenih mreža na informativne programe javne $i$ komercijalnih televizija, doktorska disertacija, Osijek, 2019.

- Tkalec, Gordana - Krušelu, ŽeljKo, Uredništvo - koncepti uredivanja u predigitalno i digitalno doba, Centar za digitalno nakladništvo, Sveučilište Sjever, Koprivnica, 2019.

- Tomašić, AdrianA, „Vjerodostojnost medijskih objava na javnome radiju“, MediAnali, Dubrovnik, god. IV. (2010.) br. 7., str. 127. -138 .

- Tomić, Zoran, Politički marketing - načela i primjena, Sveučilište u Mostaru - Synopsis, Mostar - Zagreb - Sarajevo, 2014.

- Tomić, Zoran, Odnosi s javnošću - Teorija i praksa, Synopsis, Zagreb - Sarajevo, 2016.

- Tomić, Zoran, Politički odnosi s javnošću, Synopsis, Zagreb Sarajevo, 2017.

- Tucaković, ŠEmso, Leksikon mas-medija, Prosperitet, Sarajevo, 2004.

- Volarević, Marija - Bebić, Domagoj, „Društvene mreže kao izvor vijesti u najgledanijim središnjim informativnim emisijama u Hrvatskoj", Medijske studije, Zagreb, god. IV. (2013.) br. 8., str. 60. -74 .

- Wagemans, Andrea - Witschge, Tamara- Deuze, Mark, „Ideology as Resource in Entrepreneurial Journalism: The French 
online news startup Mediapart", Journalism Practice, Taylor \& Francis, god XI. (2016.) br. 2., str. 16o. - 177.

- Žlof, Ksenija- Herljević, Zlatko - Hadžić, Slobodan, „Predodžbe novinara o važnosti društvenih mreža u proizvodnji medijskih sadržaja", Media, culture and public relations, Zagreb, god. V. (2013.) br. 1., str. 17. - 29. 


\section{ONLINE MEDIA AND JOURNALISM ON SOCIAL NETWORKS - CASE STUDY SOCIAL NETWORK FACEBOOK}

\section{Abstract}

Media and journalism have survived revolutionary changes through development of internet and information and communications technologies while the multimedia character of news processing has changed forms of collecting, production, editing and publishing news. The case study on the Facebook editing policies of the ten most widely read news portals in Croatia confirms that traditional journalism values, good and objective journalism are under strong pressure of productivity, efficiency and profitability and that online media are becoming more dependent on social networks. News portals abundantly use clickbaiting and other manipulative techniques in order to increase readership of the social media posts or increase virality of some "soft" news. The influence of news portals grows with everyday increase of the number of followers in social networks, whereas dominance of Facebook is significantly higher and it is not under question for the time being.

Keywords: online media; social networks; fake news; media manipulation; sources of information; digital marketing; public interest 